\title{
Reduction of Airway-Related Complications by Dexmedetomidine in Nasal Surgeries
}

\author{
AHMED M. ABD ELGALEEL, M.D. and AHMED G.M. HEGAZY, M.D. \\ The Department of Anesthesiology and Intensive Care, Faculty of Medicine, Al-Azhar University
}

\begin{abstract}
Background: Nasal surgeries can stimulate various sites from the nasal mucosa to the diaphragm and the presence of endotracheal tube can induce some complications like coughing, laryngospasm and laryngeal oedema . To reduce airway reflexes, tracheal extubation should be performed by special technique or use of some drugs as dexmedetomidine which has sedative and analgesic effects, without affecting respiratory status.
\end{abstract}

Aim of Study: The primary outcome of this study is to evaluate the effect of dexmedetomidine adminstration on airway reflexes during extubation in nasal surgeries, the secondry outcome of this study is evaluation of hemodynamic response to the added medication (dexmedetomidine) and way of extubation.

\section{Patients and Methods:}

Type of study: Prospective randomized single-blinded, clinical comparative study.

Number of Patients: 60 patients of both sexes, (ASA) class I and II, admitted for elective nasal surgeries, randomly allocated into two groups each of 30 patients, Group N: "No Stimulation" technique, This technique avoids extubation under light anesthesia and ensures extubation only when consciousness is returned. It requires absolutely no stimulation during emergence and performing extubation only when the patient wakes up spontaneously and opens his eyes. Group D: Dexmedetomidine-group, who received intravenous (I.V) dexmedetomidine $0.5-1 / \mathrm{g} / \mathrm{g}$ bolus in $100 \mathrm{ml}$ of normal saline over 10 minutes at the end of surgery, followed by $0.2 \mathrm{pg} / \mathrm{kg} / \mathrm{hr}$ which was stopped immediately when extubation was done.

Results: The following parameters were assessed between the two groups: Airway reflexes, hemodynamics, extubation time, Regarding airway reflexes (coughing, bucking, laryngospasm and oozing from the wound) the results of our study showed that the incidence of coughing and bucking were significantly less in group D more than group N. As regard hemodynamic response the present results showed that the changes in MAP during emergence extubation were significantly less in dexmedetomidine group than "No Stimulation" technique group. As regard extubation time it was prolonged in group $\mathrm{N}$ more than groups $\mathrm{D}$.

Correspondence to: Dr. Ahmed G.M. Hegazy, The Department Anesthesiology and Intensive care, Faculty of Medicine, Al-Azhar, University
Conclusion: This study showed that the use of dexmedetomidine reduce the airway reflexes and hemodynamic response further to the advantage of short extubation time compared with the "No Stimulation" technique.

Key Words: Recovery - Airway reflexes - Nasal surgeries Technique - Tracheal - "No Stimulation" - Rhinoplasty - Dexmedetomidine.

\section{Introduction}

INTUBATION and extubation are associated with airway and hemodynamic response leading to cough induction, bronchospasm, tachycardia, hypertension, arrhythmia, myocardial ischemia, increased bleeding, increased intracranial and intraocular pressure [13].

Tracheal extubation can be performed while patients are awake or under deep anesthesia. Both techniques have their pros and cons, Extubation in a light plane of anesthesia is the concern in awake extubation while leaving the patient with an unprotected airway is the reservation in deep extubation [15].

When a patient is deeply anesthetized, tracheal extubation during nasal surgeries can be difficult due to possibility of aspiration by blood and secretions existed in the pharynx, and difficulty performing manual ventilation by face mask [2].

On the other hand when a patient is lightly anesthetized, extubation can stimulate reflex responses via tracheal and laryngeal irritation [5]

Deep extubation decrease cardiovascular response and reduces the incidence of airway reflexes. However, the incidence of respiratory complications has been found to be greater after deep extubation [14].

For Smooth extubation we must avoid the straining, movement, coughing, breath holding and laryngospasm [12]. 
Much theories have been described for cardiovascular stimulation during extubation such as surge of catecholamines, airway irritation and intense pain following surgery. Although these changes are transitory, it could be a major concern for an anesthesiologist [16]

To attenuate these changes during extubation many trials have been done using, I.V lignocaine [10], short acting opioids such as fentanyl and remifentanil [11], esmolol [19], labetalol [12] and verapamil [8], have been used to attenuate both hemodynamic and airway responses during extubation but with certain limitations.

The "No Stimulation" technique has been suggested, It requires absolutely no stimulation during emergence and performing extubation only when the patient wakes up spontaneously and opens his eyes, and avoids extubation under light plan of anesthesia and ensures extubation only when consciousness is returned [22]

Recent trials using $\alpha 2$-adrenoreceptor agonist as an adjuvant to facilitate extubation in surgical intensive care unit, but its role in the attenuation of hemodynamic and airway reflexes during extubation in GA is still scarce. The effects of single dose of dexmedetomidine in attenuation of the airway and circulatory reflexes during extubation still under research [17].

\section{Aim of this study:}

The primary outcome of this study is to evaluate the effects of dexmedetomidine adminstration on airway reflexes during extubation in nasal surgeries, the secondry outcome of this study is evaluation of hemodynamic response to the added medication and way of extubation.

Airway reflexes (coughing, bucking, laryngospasm, the incidence of vomiting), hemodynamics, extubation time between two groups and determined convenient technique for tracheal extubation were investigated.

Sample size: Sample Size Calculation is presented as a public service of Creative Research Systems survey software. You can use it to determine how many people you need to interview in order to get results that reflect the target population as precisely as needed. Generally, the sample size for any study depends on the: Acceptable level of significance, Power of the study, Expected effect size, Underlying event rate in the population and Standard deviation in the population. Some more factors that can be considered while calculating the final sample size include the expected dropout rate, an unequal allocation ratio, and the objective and design of the study.

Sample size calculation: There are several methods used to calculate the sample size depending on the type of data or study design. The sample size is calculated using the following formula:

$$
\mathrm{n}=2(\mathrm{Za}+\mathrm{Z} 1-\beta) 2 \sigma 2 / \Delta 2
$$

where $\mathrm{n}$ is the required sample size. For $\mathrm{Z1}$ $, \beta, Z$ is a constant set by convention according to power of the study. In the above-mentioned formula $\sigma$ is the standard deviation (estimated) and $\Delta$ the difference in effect of two interventions which is required (estimated effect size). This gives the number of sample per arm in a controlled clinical trial.

\section{Patients and Methods}

Type of study: Prospective randomized singleblinded, clinical comparative study.

\section{Duratione and place of study:}

This study was conducted from May 2018 and ended at Jun 2019 in Al-Azhar University Hospitals (El-Hussein and Sayed Galal) and approved by the ethics committee from the Department of Anesthesia of Fucultyof Medicine Al-Azhar University and patients' written informed consent was obtained.

\section{Patients:}

This study included 60 patients of both sexes, ASA class I and II, aged between 18-35 years, admitted for elective nasal surgeries, They were randomly allocated into two equal groups by computer generated randomization and sealed opaque envelopes, 30 patients each $(n=30)$.

- Group (N): "No Stimulation" technique.

- Group (D): Dexmedetomidine-group.

\section{Exclusion criteria:}

1- Patients under treatment with sedatives, antitussives, or angiotensin-converting enzyme inhibitors.

2- Patients with history of current or chronic upper airway disease, asthma, chronic obstructive airway diseases and chronic cough and difficult airway intubation.

3- Patients with systemic illnesses (eg, hypertension [systolic BP $(\mathrm{SBP})>160 \mathrm{~mm} \mathrm{Hg}$ ], diabetes mellitus.

4- Any contraindication to use medications. 


\section{Preoperative evaluation:}

Routine preoperative assessment clinical and laporatory by full history taking, physical examination including air way, chest and heart examination and investigations (CBC, PT, PTT, INR and chest X-Ray).

\section{Methods:}

All patients were received $10 \mathrm{mg} / \mathrm{kg}$ of I.V paracetamol as preemptive analgesia, and I.V ondansetron $4 \mathrm{mg}$ for the prevention of postoperative nausea and vomiting thirty minutes before the end of surgery. preoxygenation was done 3 minutes before induction of anesthesia.

Induction: All patients received fentanyl 1$2 \mathrm{gg} / \mathrm{kg}$ and after 2 minutes, Propofol was given in dose $2 \mathrm{mg} / \mathrm{kg}$ throughout 90 seconds and the endotracheal intubation facilitated with rocuronium bromide $0.5 \mathrm{mg} / \mathrm{kg}$ IV. And maintained by $0.3 \mathrm{mg} / \mathrm{kg}$ shots on demand. The tracheal tube (TT) size was chosen 7 to $7.5 \mathrm{~mm}$ internal diameter in females and 8 to $8.5 \mathrm{~mm}$ internal diameter in males, and the cuff was inflated with air, and cuff-pressure was monitored and maintained at 20 mbar by aneroid manometer throughout the procedure. Topical nasal application of $1 \%(10 \mathrm{mg} / \mathrm{ml})$ lidocaine with 1: 200000 adrenaline was allowed for all patients to reduce bleeding during surgery by surgeon. Gauze throat pack was inserted under vision by direct laryngoscope in each patient and eye lubricant was applied.

Maintainance: After tracheal intubation, anesthesia was maintained with $2 \%$ sevoflurane in a mixture of $50 \%$ oxygen in air via a closed-circuit system. During mechanical ventilation the respiratory rate and tidal volume were adjusted to maintain the end-tidal $\mathrm{CO} 2$ (ETCO2 32-38 $\mathrm{mm} \mathrm{Hg}$ ) intraoperatively.

Monitoring: Basic monitoring for all patients consisted of noninvasive BP measurement, (HR), electrocardiograph (ECG), pulse oxygen saturation $(\mathrm{SpO} 2)$ and end-tidal $\mathrm{CO} 2$ values.

At the end of surgery any residual neuromuscular blockade, was reversed by I.V neostigmine plus atropine. The patient was allowed to breathe spontaneously sevoflurane and oxygen in air $40 \%$, the nose was packed by a nasal packing, and we will extubate the patient according to computer generated randomization and sealed opaque envelopes.

Group N: "No Stimulation" technique (absolutely no stimulation was allowed until patients were able to open their eyes), at the end of the procedure, while the patient was still adequately anesthetized, throat pack was removed, any blood and secretions in the pharynx were carefully suctioned under direct visualization in order to confirm that secretion clearance was complete and to avoid trauma to the mucosa. The TT cuff was deflated, and then the patients were turned to the lateral (recovery) position. After this, sevoflurane was discontinued and fresh gas flow was increased, and if the patient did not breath spontaneously, positive pressure ventilation was continued with $100 \%$ oxygen until spontaneous ventilation returned. Tracheal extubation was performed when the patient regained consciousness, had enough spontaneous breathing, intact gag reflex, but absolutely no stimulation was allowed until patients spontaneously wake up and were able to open their eyes.

Group D: Dexmedetomidine - group, At the end of surgery, after completion of the procedure, sevoflurane was immediately discontinued and fresh gas flow was increased, and started to give a bolus dose of dexmedetomidine $0.5-1 \mu \mathrm{g} / \mathrm{kg}$ in $100 \mathrm{ml}$ of normal saline over 10 minutes then, after bolus dose has been finished we started to give a continuous maintenance infusion dose of dexmedetomidine $0.2 \mathrm{ug} / \mathrm{kg} / \mathrm{hr}$, which must be stopped when extubation was done. Throat pack was removed, any blood and secretions in the pharynx were carefully suctioned, and the patients were then turned to the lateral (recovery) position. If the patient did not breath spontaneously, positive pressure ventilation was continued with $100 \%$ oxygen until spontaneous ventilation returned. Tracheal extubation was performed when the patient regained consciousness, had sufficient spontaneous breathing, intact gag reflex, purposeful movement, and spontaneous eye opening.

After extubation in the two groups, the patients breathed $40 \%$ oxygen by face mask until they were able to maintain a patent airway, and consequently they were transported to the post anesthesia care unit (PACU). Pulse oximetry was provided continuously, intraoperatively, during transport, and throughout recovery period (was mandatory).

\section{The following parameter will be measured:}

Severity of coughing was defined as 0 if no coughing occurred; 1 if a single cough occurred and $\mathrm{SpO}_{2}>-95 \% ; 2$ if multiple coughs occurred and $\mathrm{SpO}_{2}>-95 \% ; 3$ if multiple coughs occurred and $\mathrm{SpO}_{2}<95 \%$; and 4 if multiple coughs occurred, $\mathrm{SpO}_{2}<95 \%$, and coughing required administration of i.v. medication (Sheta et al., 2011). 
The incidence and severity of laryngospasm according to a four-point scale $(0=$ No laryngospasm, $1=$ Stridor on inspiration, $2=$ Total occlusion of the vocal cords (silence with no air movement), or $3=$ cyanosis) was reported (Sheta et al., 2011.

The incidences of hoarseness of voice and sore throat were also reported in the first 24 hours postoperatively.

The incidence of vomiting in the recovery room was reported.

Extubation Time (from end of sevoflurane administration until extubation) was measured in all groups, (HR), (SBP) and diastolic blood pressures(DBP) were measured at the end of surgery, which served as baseline values. Subsequent measurements were taken at 2, 4, 5, 10, 15, 20, 25, and 30 minutes after the end of surgery.

\section{Statistical analysis:}

Recorded data were analyzed using the statistical package for social sciences, version 20.0 (SPSS Inc., Chicago, Illinois, USA). Quantitative data were expressed as mean \pm standard deviation (SD). Qualitative data were expressed as frequency and percentage. Probability ( $p$-value): $p$-value $<0.05$ was considered significant, $p$-value $<0.001$ was considered as highly significant, $p$-value $>0.05$ was considered insignificant.

\section{Results}

Table (1): Demographic data.

\begin{tabular}{lcccc}
\hline $\begin{array}{c}\text { Demographic } \\
\text { Data }\end{array}$ & $\begin{array}{c}\text { Group (N): } \\
\text { No } \\
\text { Stimulation } \\
(\mathrm{n}=30)\end{array}$ & $\begin{array}{c}\text { Group (D): } \\
\text { Dexme- } \\
\text { detomidine } \\
(\mathrm{n}=30)\end{array}$ & F/x2\# & $\begin{array}{c}p- \\
\text { value }\end{array}$ \\
\hline $\begin{array}{l}\text { Age (years) } \\
\text { BMI [wt/(ht)^2] }\end{array}$ & $28.31 \pm 4.39$ & $28.82 \pm 5.30$ & 0.784 & 0.436 \\
Gender: & $33.78 \pm 6.57$ & $34.78 \pm 6.57$ & 0.016 & 0.760 \\
$\quad$ Male & $19(63.3 \%)$ & $20(66.7 \%)$ & $1.202 \#$ & 0.459 \\
$\quad$ Female & $11(36.7 \%)$ & $10(33.3 \%)$ & & \\
ASA stratus: & & & & \\
$\quad$ I & $20(66.7 \%)$ & $22(73.3 \%)$ & $0.373 \#$ & 0.830 \\
$\quad$ II & $10(33.3 \%)$ & $8(26.7 \%)$ & & \\
Type of surgery: & & & & \\
$\quad$ Rhinoplasty & $12(40 \%)$ & $13(43.3 \%)$ & $2.395 \#$ & 0.664 \\
$\quad$ FEES & $8(26.7 \%)$ & $9(30.0 \%)$ & & \\
$\quad$ Turbinectomy & $10(33.3 \%)$ & $8(26.7 \%)$ & & \\
\hline
\end{tabular}

F- One Way Analysis of variance.

\#x2: Chi-square test.

All data expressed by Mean \pm SD.

Post HOC: $\dagger$ Significant difference between group N.

$p$-value $>0.05 \mathrm{NS}$. $* * p$-value $<0.05 \mathrm{~S}$. $* * * x$-value $<0.001 \mathrm{HS}$

This table shows statistically non-significant (NS) difference between the groups regarding demographic data.
Table (2): Comparison between the groups regarding extubation Time (min).

\begin{tabular}{|c|c|c|c|c|}
\hline $\begin{array}{l}\text { Extubation } \\
\text { Time (min) }\end{array}$ & $\begin{array}{l}\text { Group }(\mathrm{N}): \\
\text { No } \\
\text { Stimulation } \\
(\mathrm{n}=30)\end{array}$ & $\begin{array}{l}\text { Group (D): } \\
\text { Dexme- } \\
\text { detomidine } \\
(\mathrm{n}=30)\end{array}$ & ANOVA & $\begin{array}{c}p- \\
\text { value }\end{array}$ \\
\hline $\begin{array}{l}\text { Extubation } \\
\text { Time (min) }\end{array}$ & $15.34 \pm 2.59$ & $8.15 \pm 4.35 \ddagger$ & 9.144 & $<0.001 * *$ \\
\hline
\end{tabular}

All data expressed by Mean \pm SD

Post HOC: $\dagger$ Significant difference between group N.

$p$-value $>0.05 \mathrm{NS}$. ${ }^{*} p$-value $<0.05 \mathrm{~S}$. $* * *$-value $<0.001 \mathrm{HS}$.

This table shows statistically significant difference between the groups regarding extubation time (min).

Table (3): Comparison between the groups regarding coughing.

\begin{tabular}{lllll}
\hline Coughing & $\begin{array}{c}\text { Group }(\mathrm{N}): \\
\text { No } \\
\text { Stimulation } \\
(\mathrm{n}=30)\end{array}$ & $\begin{array}{c}\text { Group (D): } \\
\text { Dexme- } \\
\text { detomidine } \\
(\mathrm{n}=30)\end{array}$ & $\begin{array}{c}\text { Chi- } \\
\text { square } \\
\text { test }\end{array}$ & $\begin{array}{c}p- \\
\text { value }\end{array}$ \\
\hline Grade 0 & $3(10.0 \%)$ & $21(70 \%) \dagger$ & 43.977 & $<0.001^{* *}$ \\
Grade 1 & $22(73.3 \%)$ & $6(20 \%) \dagger$ & 10.201 & $0.006^{*}$ \\
Grade 2 & $5(16.7 \%)$ & $3(10 \%) \dagger$ & 26.855 & $<0.001^{* *}$ \\
Grade 3 & $0(0.0 \%)$ & $0(0 \%)$ & 0.000 & 1.000 \\
Grade 4 & $0(0.0 \%)$ & $0(0 \%)$ & 0.000 & 1.000 \\
\hline
\end{tabular}

Post HOC: $\uparrow$ Significant difference between group N.

$p$-value $>0.05 \mathrm{NS}$. **p $p$-value $<0.05 \mathrm{~S}$. ***p -value $<0.001 \mathrm{HS}$.

This table shows statistically significant difference between the groups regarding coughing Grade 1 and highly significant at grade 0,2 .

Table (4): Comparison between the groups regarding laryngospasm.

\begin{tabular}{lllll}
\hline $\begin{array}{c}\text { Laryngo- } \\
\text { spasm }\end{array}$ & $\begin{array}{c}\text { Group (N): } \\
\text { No } \\
(\mathrm{n}=30)\end{array}$ & $\begin{array}{c}\text { Group (D): } \\
\text { Dexme- } \\
\text { detomidine } \\
(\mathrm{n}=30)\end{array}$ & $\begin{array}{c}\text { Chi- } \\
\text { square } \\
\text { test }\end{array}$ & $\begin{array}{c}p \text { - } \\
\text { value }\end{array}$ \\
\hline Grade 0 & $29(96.7 \%)$ & $30(100 \%) \dagger$ & 9.604 & $0.008^{*}$ \\
Grade 1 & $1(3.3 \%)$ & $0(0 \%) \dagger$ & 6.506 & $0.044^{*}$ \\
Grade 2 & $0(0.0 \%)$ & $0(0 \%)$ & 0.000 & 1.000 \\
Grade 3 & $0(0.0 \%)$ & $0(0 \%)$ & 0.000 & 1.000 \\
\hline
\end{tabular}

Post HOC: $\uparrow$ Significant difference between group N. $p$-value $>0.05 \mathrm{NS}$. * $p$-value $<0.05 \mathrm{~S}$.

This table shows statistically significant difference between the groups regarding laryngospasm Grade 0 and grade 1 . 
Table (5): Comparison between the groups regarding airway events-related complications.

\begin{tabular}{|c|c|c|c|c|}
\hline $\begin{array}{l}\text { Airway Events- } \\
\text { related } \\
\text { Complications }\end{array}$ & $\begin{array}{c}\text { Group }(N): \\
\text { No } \\
\text { Stimulation } \\
(n=30)\end{array}$ & $\begin{array}{l}\text { Group (D): } \\
\text { Dexme- } \\
\text { detomidine } \\
(\mathrm{n}=30)\end{array}$ & $\begin{array}{l}\text { Chi- } \\
\text { square } \\
\text { test }\end{array}$ & $\begin{array}{c}p- \\
\text { value }\end{array}$ \\
\hline Breath holding & $3(10.0 \%)$ & $0(0 \%) \dagger$ & 21.132 & $<0.001 * *$ \\
\hline $\begin{array}{l}\text { Sever } \\
\text { desaturation } \\
\text { Episodes } \\
\left(\mathrm{SpO}_{2}<90 \%\right)\end{array}$ & $0(0.0 \%)$ & $0(0 \%)$ & 0.000 & 1.000 \\
\hline Hoarseness & $0(0.0 \%)$ & $0(0 \%)$ & 0.000 & 1.000 \\
\hline
\end{tabular}

Post HOC: $†$ Significant difference between group N.

$p$-value $>0.05 \mathrm{NS}$. $* * p$-value $<0.05 \mathrm{~S}$. *** $p$-value $<0.001 \mathrm{HS}$.

This table shows statistically significant difference between the different groups regarding airway events related complications.

Table (6): Comparison between the groups regarding HR (beat $/ \mathrm{min}$ ).

\begin{tabular}{ccccc}
\hline $\begin{array}{c}\text { Heart Rate } \\
\text { (beat/min) }\end{array}$ & $\begin{array}{c}\text { Group }(\mathrm{N}): \\
\text { No } \\
(\mathrm{n}=30)\end{array}$ & $\begin{array}{c}\text { Group (D): } \\
\text { Dexme- } \\
\text { detomidine } \\
(\mathrm{n}=30)\end{array}$ & $\begin{array}{c}\text { Chi- } \\
\text { square } \\
\text { test }\end{array}$ & $\begin{array}{c}p- \\
\text { value }\end{array}$ \\
\hline Baseline & $81.12 \pm 4.06$ & $79.09 \pm 3.95$ & 1.963 & 0.159 \\
(end of & & & & \\
surgery) & & & & \\
At 2min. & $81.12 \pm 4.06$ & $78.08 \pm 3.90$ & 1.596 & 0.149 \\
At 5min. & $84.16 \pm 4.21$ & $75.04 \pm 3.75 \dagger$ & 9.706 & $0.002 *$ \\
At 10min. & $98.36 \pm 4.92$ & $74.02 \pm 3.70 \dagger$ & 6.525 & $0.034 *$ \\
At 15min. & $102.41 \pm 5.12$ & $69.97 \pm 3.50 \dagger$ & 12.080 & $<0.001 * *$ \\
At 20min. & $99.37 \pm 4.97$ & $76.05 \pm 3.80 \dagger$ & 7.178 & $0.019 *$ \\
At 25min. & $90.25 \pm 4.51$ & $86.16 \pm 4.21$ & 0.525 & 0.468 \\
At 30min. & $84.16 \pm 4.21$ & $81.12 \pm 4.06$ & 0.034 & 0.854 \\
\hline
\end{tabular}

All data expressed by Mean $\pm \mathrm{SD}$

Post HOC: $†$ Significant difference between group $\mathrm{N}$.

$p$-value $>0.05 \mathrm{NS}$. $* p$-value $<0.05 \mathrm{~S}$. $* * p$-value $<0.001 \mathrm{HS}$

This table shows statistically significant difference between the groups regarding HR at 5,10,20 and highly significant at $15 \mathrm{~min}$.

Table (7): Comparison between the groups regarding MAP $(\mathrm{mmHg})$.

\begin{tabular}{lcccc}
\hline $\begin{array}{c}\text { Mean arterial } \\
\text { pressure } \\
(\mathrm{mmHg})\end{array}$ & $\begin{array}{c}\text { Group (N): } \\
\text { No } \\
\text { Stimulation } \\
(\mathrm{n}=30)\end{array}$ & $\begin{array}{c}\text { Group (D): } \\
\text { Dexme- } \\
\text { detomidine } \\
(\mathrm{n}=30)\end{array}$ & $\begin{array}{c}\text { Chi- } \\
\text { square } \\
\text { test }\end{array}$ & $\begin{array}{c}p- \\
\text { value }\end{array}$ \\
\hline $\begin{array}{c}\text { Baselin } \\
\text { (end of }\end{array}$ & $80.53 \pm 5.53$ & $84.61 \pm 5.83$ & 0.525 & 0.468 \\
surgery) & & & & \\
At 2min. & $80.53 \pm 5.53$ & $82.55 \pm 5.63$ & 0.683 & 0.140 \\
At 5min. & $86.58 \pm 5.73$ & $77.51 \pm 5.48 \dagger$ & 9.380 & $0.009^{*}$ \\
At 10min. & $94.68 \pm 6.08$ & $80.48 \pm 5.37 \dagger$ & 7.527 & $0.023^{*}$ \\
At 15min. & $97.68 \pm 6.08$ & $79.47 \pm 5.32 \dagger$ & 8.038 & $0.011^{*}$ \\
At 20min. & $95.68 \pm 6.08$ & $86.58 \pm 5.73 \dagger$ & 5.011 & $0.029^{*}$ \\
At 25min. & $92.67 \pm 6.03$ & $90.65 \pm 5.98$ & 0.034 & 0.854 \\
At 30min. & $89.67 \pm 6.03$ & $87.60 \pm 5.78$ & 0.095 & 0.758 \\
\hline
\end{tabular}

All data expressed by Mean \pm SD.

Post HOC: $\dagger$ Significant difference between group N.

$p$-value $>0.05 \mathrm{NS}$. $* * p$-value $<0.05 \mathrm{~S}$. $* * * p$-value $<0.001 \mathrm{HS}$.
This table shows statistically significant difference between the groups regarding MAP $(\mathrm{mmHg})$ At 5,10,15, and 20min.

\section{Discussion}

Regarding airway reflexes (coughing, bucking, laryngospasm and oozing from the wound) the results of our study showed that the incidence of coughing and bucking were significantly less in group D more than group $\mathrm{N}$ which can be explained as the TT and its cuff stimulate the rapidly acting irritant and the stretch receptors in the trachea [18] Those irritant receptors are assumed to be the receptors involved in the cough reflex [3]. The blockade of these receptors is the theoretical reason behind inhibition of the cough reflex during extubation by topical application of local anesthetics [4].

In dexmedetomidine group $0.5 \mathrm{~g} / \mathrm{kg} \mathrm{LV}$ before tracheal extubation was associated with significantly less coughing and better quality of extubation than group $\mathrm{N}$ because dexmedetomidine, is a potent alpha 2 adrenoceptor agonist, decrease the sympathetic outflow and noradrenergic activity thereby and possessed both sedated and analgesic activity [9].

Our results were coincided with [8]. Who reported that dexmedetomidine $0.5 \mathrm{~g} / \mathrm{k}$ w was associated with attenuation of the prevalence and severity of airway-related complications on emergence from anesthesia in intraocular surgery, without prolonged recovery. Cough scores were significantly lower in the dexmedetomidine group than in the placebo group $(p<0.05)$, but there were no differences between-group in the prevalence of breath holding and desaturation.

Our results were also, coincided with [1]. Who did a similar study comparing fentanyl with dexmedetomidine. The fentanyl group had a similar prevalence of cough (70\%), 20\% of which was severe. The lower prevalence of cough (15\%) found with dexmedetomidine compared with fentanyl suggests that dexmedetomidine was more effective for improving the quality of extubation.

[6] Who did a similar study comparing remifentanil with two doses of dexmedetomidine $0.5 \mathrm{~g} / \mathrm{kg}$ and $0.7 \mathrm{~s} / \mathrm{k}$ for otology surgery and observed that higher percentage of patients in dexmedetomidine group had smooth extubation regarding the absence of bucking and coughing with head movement during surgical dressing, they also observed the incidence of postoperative nausea and vomiting was less with dexmedetomidine group. 
As regard laryngeal spasm, both groups $\mathrm{N}$ and $\mathrm{D}$ in the present study, showed no case of laryngeal spasm or severe desaturation episodes. Less airway stimulation and smooth recovery adopted by "non touch" technique and dexmedetomidine can again explain the lower incidence of laryngeal spasm. Another explanation is lesser oozing from the wound. Bleeding from surgical sites and leakage of blood through postnasal space can contaminate the vocal folds, potentially giving rise to laryngeal spasm and these results were coincided with that obtained by $[\mathbf{1 , 2 0}]$.

As regard hemodynamic response the present results showed that the changes in MAP during emergence extubation were significantly less in dexmedetomidine group than "No Stimulation" technique group.

Recovering from anesthesia often results in elevated catecholamine concentration following anesthetic withdrawal which is further aggravated by laryngeal manipulation occurring during extubation.

There were significantly lower increases in MAP after extubation in patients who received dexmedetomidine compared with group $\mathrm{N}$ and this was coincided with [11], who found that a single dose of dexmedetomidine $0.5 \mu \mathrm{g} / \mathrm{kg}$ given $5 \mathrm{~min}$ before extubation produced better attenuation of hemodynamic response in craniotomy patients, However, [18] found decrease in mean arterial pressure after $5 \mathrm{~min}$ from baseline value.

Our results were coincided with [8]. who reported that dexmedetomidine $0.5 \mathrm{gg} / \mathrm{kg}$ was associated with attenuation of circulatory reflexes on emergence from anesthesia in intraocular surgery, without prolonged recovery. MAP was significantly increased from baseline at extubation in both groups $(p<0.05)$, but the increase was significantly less substantial with dexmedetomidine.

Our results were also coincided with [6]. who compared the effects of dexmedetomidine with isotonic saline on hemodynamic changes in patients who had undergone vascular surgery. That study found that the dexmedetomidine I.V infusion was associated with significant attenuation of increases in MAP and plasma catecholamine concentrations during emergence from anesthesia compared with placebo $(p<0.05)$.

Regarding extubation time (from the time of sevoflurane closure until extubation), it was prolonged in group $\mathrm{N}$ more than groups $\mathrm{D}$.
Our results showed that extubation time was prolonged in group $\mathrm{N}$ more than group $\mathrm{D}$.

In dexmedetomidine group extubation time was shorter than group $\mathrm{N}$ and this was explained as the distribution phase of dexmedetomidine is rapid, with a half-life of distribution of approximately 6 minutes and elimination half-life of 2 hours. The average protein binding is $94 \%$ and is constant across the different plasma concentrations and similar in males and females [7].

Therefore, this technique (dexmedetomidine) is a safe alternative for tracheal extubation and it may be favored as extubation technique of choice, particularly in airway surgery or when the patient or surgical risk factors require that coughing and hypertension during emergence from anesthesia is prohibited.

\section{Conclusion:}

From the previous results we can conclude that the dexmedetomidine group was associated with minimal hemodynamic response and airway reflexes without prolonged recovery compared with the "No Stimulation" technique.

\section{References}

1- AKSU R., AKIN A., BIÇER C., ESMAOGLU A., et al.: Comparison of the effects of dexmedetomidine versus fentanyl on airway reflexes and hemodynamic responses to tracheal extubation during rhinoplasty: A double-blind, randomized, controlled study. Curr. Ther. Res. Clin. Exp., 70: 209-20, 2009.

2- ANWARI J.S. and BHATTI J.: Use of laryngeal mask airway for the care of rhinoplasty. Saudi Med. J., 26: 494495, 2005.

3- CANNING B.J.: Anatomy and neurophysiology of the cough reflex: ACCP evidence-based clinical practice guidelines. Chest, 129: 33S-47, 2006.

4- DIACHUN C.A., TUNINK B.P. and BROCK-UTNE J.G.: Suppression of cough during emergence from general anesthesia: Laryngotracheal lidocaine through a modified endotracheal tube. J. Clin. Anesth., 13: 447-51, 2001.

5- FAGAN C., FRIZELLE H.P., LAFFEY J., HANNON V., et al.: Th effects of intracuff lidocaine on endotrachealtube-induce emergence phenomena after general anesthesia. Anesth Analg. 91: 201-5, 2000.

6- FAN Q., HU C., YE M. and SHEN X.: Dexmedetomidine for tracheal extubation in deeply anesthetized adult patients after otologic surgery: A comparison with remifentanil. BMC Anesthesiol., 15: 106-10, 2015.

7- GERTLER R., BROWN H.C., MITCHELL D.H. and SILVIUS E.N.: Dexmedetomidine: A novel sedativeanalgesic agent. Proc (Bayl Univ Med Cent), 14: 13-21. 2001.

8- GULER G., AKIN A., TOSUN Z., ESKITASCOGLU E., et al.: Single dose dexmedetomidine attenuates airway 
and circulatory reflexes during extubation. Acta Anaesthesiol Scand., 49: 1088-91, 2005.

9- JAIN V., CHATURVEDI A., PANDIA M.P. and BITHAL P.K.: Effect of dexmedetomidine on recovery profile of patients undergoing anterior cervical discectomy and fusion. Journal of Anaesthesiology, Clinical Pharmacology, 35 (1): 92-69, 2019.

10- JEE D. and PARK S.Y.: Lidocaine sprayed down the endotracheal tube attenuates the airway-circulatory reflexes by local anesthesia during emergence and extubation. Anesth Analg., 96: 293-7, 2003.

11- KOTHARI D., TANDON N., SINGH M. and KUMAR A.: Attenuation of circulatory and airway responses to endotracheal extubation in craniotomies for intracerebral space occupying lesions: Dexmedetomidine versus lignocaine. Anesth Essays Res., 8:78-82, 2014.

12- LUTHRA A., PRABHAKAR H. and RATH G.P.: Alleviating stress response to tracheal extubation in neurosurgical patients: A comparative study of two infusion doses of dexmedetomidine. Journal of Neurosciences in Rural Practice, 8 (1): 49-56, 2017.

13- MINOGUE S.C., RALPH J. and LAMPA M.J.: Laryngotracheal topicalization with lidocaine before intubation decreases the incidence of coughing on emergence from general anesthesia. Anesth Analg., 99:1253-7, 2004.

14- MISTRY T., PUROHIT S., ARORA G., GILL N, et al.: Attenuation of extubation responses: Comparison of prior treatment with verapamil and dexmedetomidine. Journal of Neuro anesthesiology and Critical Care, 3 (01): 0339, 2016.

15- NAQVI S.E., KHAN R.A., AHMED N., MALIK U.E., et al.: Frequncy Of laryngospasm In Awake Versus Deep Extubation After Intra Nasal Surgery. Pakistan Armed Forces Medical Journal. Oct., 31; 68 (5): 1293-99, 2018.
16- PATEL H.P., SHASHANK M.R. and SHIVARAMU B.T.: Attenuation of hemodynamic response to tracheal extubation: A comparative study between esmolol and labetalol. Anesthesia, Essays and Researches, 12 (1): 180-188, 2018.

17- RANI P., HEMANTH KUMAR V.R., RAVISHANKAR M., SIVASHANMUGAM T., et al.: Rapid and reliable smooth extubation - Comparison of fentanyl with dexmedetomidine: A randomized, double-blind clinical trial. Anesth Essays Res., 10:597-601.

18- SAFAVI M., HONARMAND A and KHAZAEI M.: The effects of propofol, ketamine and combination of them in prevention of coughing and laryngospasm in patients awakening from general anesthesia: A randomized, placebo-controlled, double blind clinical trial. Advanced Biomedical Research, 5: 64, 2016.

19- SHARMA V.B., PRABHAKAR H., RATH G.P. and BITHAL P.K.: Comparison of dexmedetomidine and lignocaine on attenuation of airway and pressor responses during tracheal extubation. J. Neuroanaesth. Crit. Care, 1: 50-5, 2014.

20- SHETA S.A., ABDELHALIM A.A. and NADA E.: Evaluation of "no touch" extubation technique on airwayrelated complications during emergence from general anesthesia. Saudi Journal of Anaethesia, 5 (2): 125-31, 2011.

21- TALKE P., CHEN R., THOMAS B. et al.: The hemodynamic and adrenergic effects of perioperative dexmedetomidine infusion after vascular surgery. Anesth Analg., 90: 834-839, 2000.

22- TSUI B.C., WAGNER A., CAVE D, ELLIOTT C., et al.: The incidence of laryngospasm with a "No Touch" extubation technique after tonsillectomy and adenoidectomy. Anesth Analg., 98: 327-9, 2004. 


\section{الحد من مضاعفات مجرى التنفس في عمليات الأنف بإستخلام عقار الديكسميدتوتوميدين فيدين}

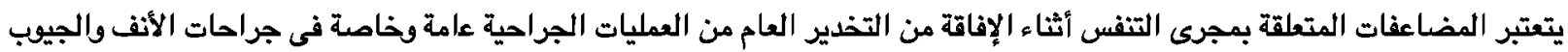

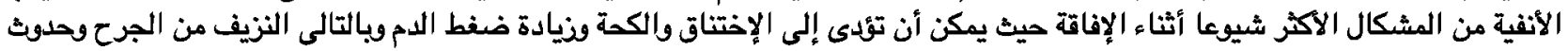
بحة في الصوت والتهاب الحلق.

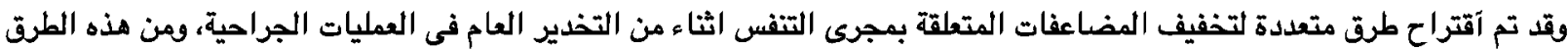

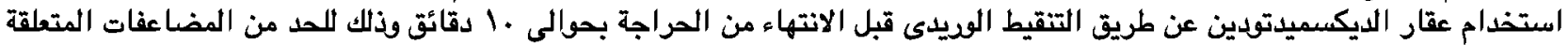
بمجرى التفس والتهيجات المصاحبة للإفاقة.

وكان الهدف من هذه الدراسة هو تقييم تأثير عقار الديكسميدتوميدين على المضاعفات المرتبطة بمجرى التفس آثناء الإفاقة من التخدير العام فى جراحات الأنف والجيوب الأنفية.

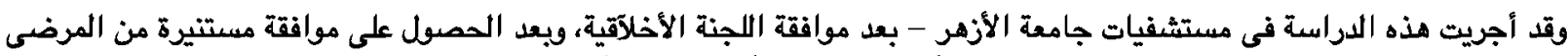

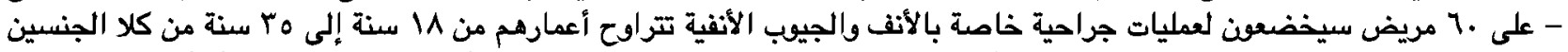

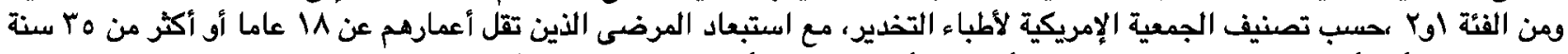

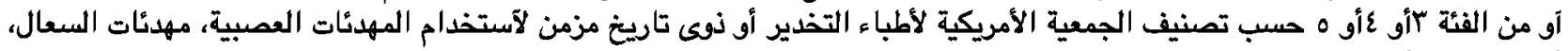

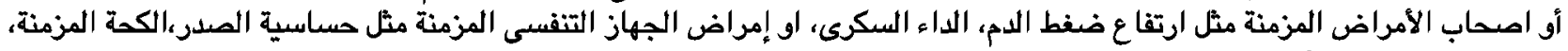
ضيق التفس المزمن، أو الذين لديهم حساسية اللدواء موضع الدماء الدراسة.

$$
\text { وقد تم تصنيف المرضى إلى مجموعتين: }
$$

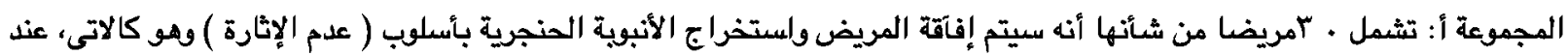

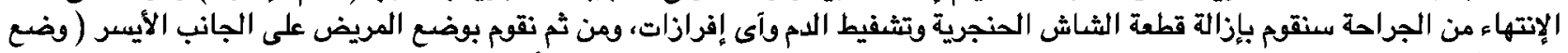

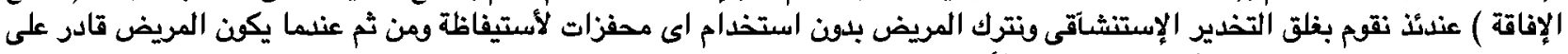

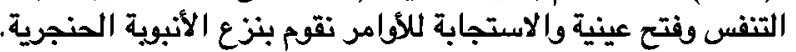

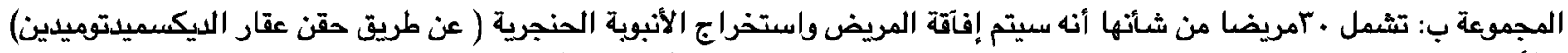

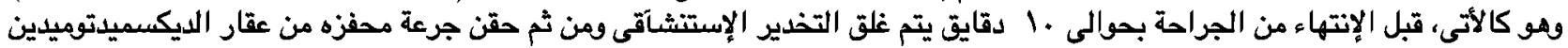

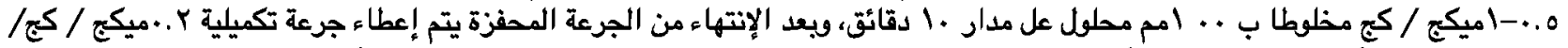

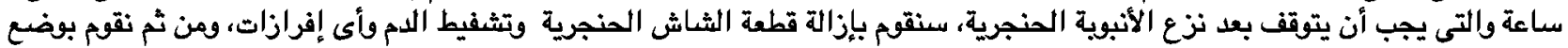

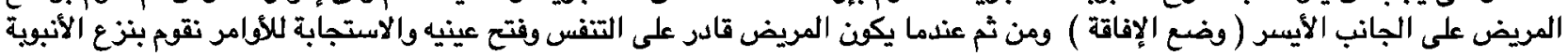

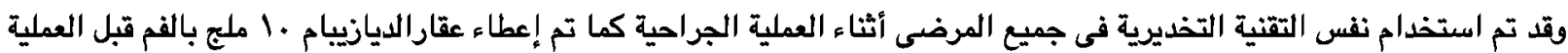

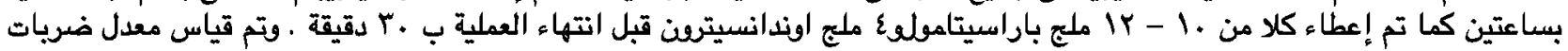

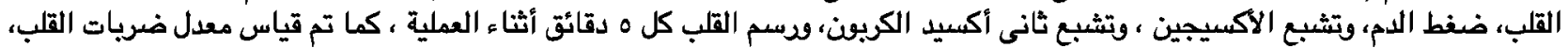

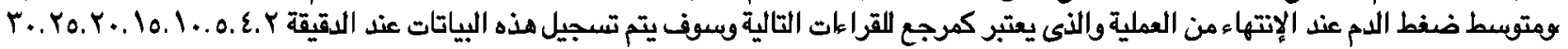

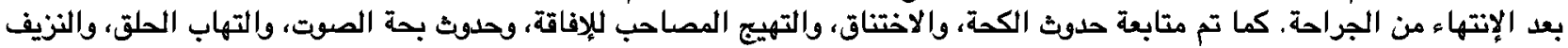

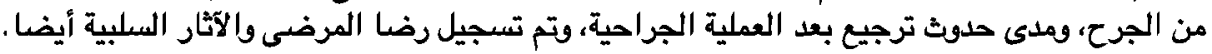

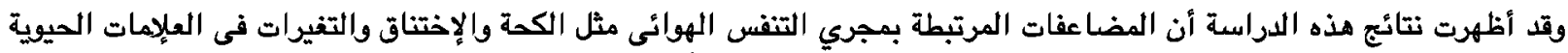

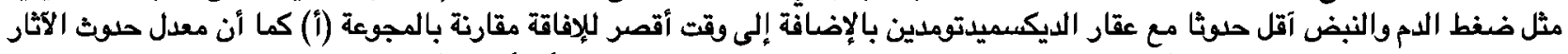

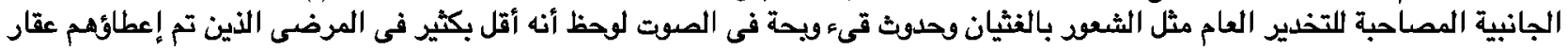
الديكسميدتويدينو كانت هذه المعدلات كلها ذات مدلولول إحصائى.

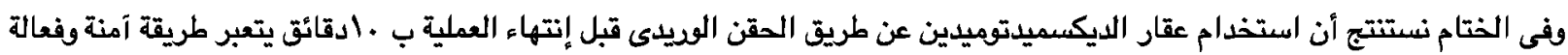

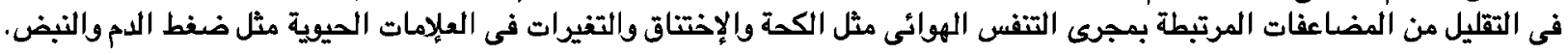

